\title{
Farming Households' Satisfaction With Quality of Agricultural Extension Services: A Case Study of Quang Binh Province, Vietnam
}

\author{
Dinh Duc Truong* \\ Faculty of Environmental, Climate Change and Urban Studies, National Economics University, Hanoi, Vietnam
}

Agriculture is an important sector of Vietnam, in which agricultural extension (AE) is a long-standing activity but was officially institutionalized in 1993 when Vietnam reformed its economic model. The AE system in Vietnam is organized quite closely from the central to local levels with various forms of AE. This study assesses the satisfaction of farmers with AE services in Quang Binh province, Vietnam. The results of a survey of 455 farmers show a positive relationship between quality and satisfaction. Factors such as assurance, reliability, and sympathy are important factors in AE service quality. The study

OPEN ACCESS

Edited by:

Philip Dobie,

World Agroforestry Centre, Kenya

Reviewed by:

Razieh Pourdarbani,

University of Mohaghegh Ardabili, Iran

Heru Irianto,

Sebelas Maret University, Indonesia

*Correspondence:

Dinh Duc Truong

truongdd@neu.edu.vn

Specialty section:

This article was submitted to Social Movements, Institutions and

Governance,

a section of the journal

Frontiers in Sustainable Food Systems

Received: 25 November 2021

Accepted: 23 December 2021

Published: 31 January 2022

Citation:

Truong DD (2022) Farming Households' Satisfaction With Quality of Agricultural Extension Services: A

Case Study of Quang Binh Province,

Vietnam.

Front. Sustain. Food Syst. 5:779477.

doi: 10.3389/fsufs.2021.779477 also provides recommendations to strengthen AE services, including updating technical information, organizing demonstration models, and stronger investment in AE systems at all levels.

Keywords: agricultural extension, service quality, farming household, factor analysis, Vietnam

\section{INTRODUCTION}

Agricultural extension services have been globally considered as an critical input for promoting agriculture and enhancing rural development (Awatade et al., 2019; Bruce and Costa, 2019). AE is defined as "the services offer technical advices on agriculture to farmers, and also supplies them with the necessary inputs and services to support their agricultural production. It provides information to farmers and passes to the farmers new ideas developed by agricultural research stations." (FAO, 2020). As time goes by, the term "agricultural extension services," while still commonly employed, has been gradually replaced by the term "agricultural advisory services." Some researchers even extend the concept more broadly to "rural advisory services" to emphasize the facilitation beyond technological transfer and to include other sources of livelihood than agriculture only (Faure et al., 2012; Kassem, 2015; Gwala et al., 2016; Baiyegunhi and Majokweni, 2019).

In Vietnam, agriculture is one of the most important economic sectors. Besides producing to serve the growing domestic demand, Vietnam is also a country that exports many agricultural products each year. The dominant crops include coffee, rubber, cashew, and rice. In recent years, aquaculture and fruit production has developed significantly and are geared toward foreign exports. With a significant contribution to gross domestic product (20\%), agriculture will continue to play a significant role in Vietnam's transition to a market economy. Vietnam's agricultural output strength is built on a large rural base $(66 \%$ of the population), where agribusiness makes up 70\% of the workforce (Nguyen and Nguyen, 2016; World Bank, 2020). To enhance agricultural development, in 1993, the Vietnamese Government issued Decree No. 13/ND-CP on Agricultural Extension, and the AE system was officially formed during the "Renovation" period. The Decree defines "AE is an activity 
of transferring technical advances, information, spreading knowledge and training skills to farmers to improve the capacity and efficiency of agricultural production and business, protect environmental protection and new rural construction" (Nguyen and Nguyen, 2016).

After nearly 30 years of operation, AE has grown strongly and has become an asynchronous system from the central to the grassroots level, closely linked with agriculture, farmers, and rural areas. At the central level, the Center for Agricultural Extension, established in 1995 under the Ministry of Agriculture and Rural Development (MARD), is the focal point for unifying direction and guidance on AE skills for the whole country. Extension organizations have also been formed and developed from the provincial to district and commune levels in the locality. AE has become an effective tool and an important bridge in transferring technical advances and new technologies, contributing to the successful growth of agricultural production in Vietnam (Dang et al., 2012; Ministry of Agricultural Rural Development, 2019).

Empirical evidence worldwide shows that AE provide timely information which support farmers in solving farming issues and in making better decisions (Buadi et al., 2013; Gwala et al., 2016; Nahayo et al., 2017). AE services also facilitate farmers' networking with management agencies and other stakeholder in agricultural value chain (Lalhmachhuana and Devarani, 2016; Morris et al., 2017; Awatade et al., 2019). In addition, AE plays an important role in organizing farmers formally or informally into groups to assist them mobilize collective actions and improve their competitiveness in local, national and international markets (Yazdanpanah et al., 2013).

However, in the face of new challenges for sustainable agriculture, AE work in Vietnam still reveals certain limitations such as the low efficiency of the extension program, the lack of diversified forms of activities, the lack of technical information and financial resources, etc. (Nguyen et al., 2016). This study aims at measuring the satisfaction level of farmers with the service quality of AE programs. The study is conducted in Quang Binh, a typical agricultural province in the central part of Vietnam. From that, some policy implications are drawn to improve the service quality of AE in the Quang Binh province and Vietnam.

\section{STUDY AREA}

Quang Binh is a province on Vietnam's North Central Coast located at the narrowest point in the east-west direction of the country's S-shaped strip $(40.3 \mathrm{~km}$ following the shortest path from the Lao border to the East Sea-Figure 1).

Quang Binh has a total land area of 9,065.27 $\mathrm{km}^{2}$. Quang Binh's mainland is located between $16^{\circ} 55^{\prime}$ and $18^{\circ} 05^{\prime}$ north latitude and $105^{\circ} 37^{\prime}$ to $107^{\circ} 00^{\prime}$ east longitude. Quang Binh has a $116.04 \mathrm{~km}$ long coastline in the east and a $201.87 \mathrm{~km}$ long borderline with Laos in the west, as well as Hon La Seaport, Dong Hoi Airport, National Route 1A, Ho Chi Minh Highway, North-South Railway, National Route 12, and provincial routes No. 20 and No. 16 that run from west to east, passing through Cha Lo International Border Gate and some border gates with Laos. The landscape of Quang Binh is narrow and hilly from west to east. Mountains and hills cover 85 percent of Quang Binh's natural land. The province is split into four major areas: high mountainous, hill and midland, plain, and coastal sand. Quang Binh is located in the tropical monsoon climate and is influenced by the north and south climates. Thus it has two different seasons: the rainy season, which lasts from September to March, and the dry season, which lasts from April to October. The yearly average rainfall fluctuates between 2,000 and 2,300 $\mathrm{mm}$. The dry season lasts from April through August, with average temperatures ranging from 24 to $25^{\circ} \mathrm{C}$. June, July, and August are the warmest months (Nguyen et al., 2015).

In 2019, the population of Quang Binh will be 8,63,350 people. Kinh ethnic people make up the majority of the population. The population is unevenly dispersed, with rural regions accounting for $84.80 \%$ and urban areas accounting for $15.20 \%$. The province is divided into six districts (Bo Trach, Le Thuy, Minh Hoa, Quang Ninh, Quang Trach, Tuyen Hoa, and Ba Don town), each having 159 communes, wards, and towns (Quang Binh People Committee, 2020).

\section{METHODOLOGY}

\section{Analytical Model}

So far, many studies have established the relationship between service quality and customer satisfaction. Perceived service quality has been widely considered as an antecedent of customer satisfaction. Previous studies have ascertained its significantly positive relationship (Getty and Getty, 2003; Hossain, 2012; Chavan and Ahmad, 2013; Faramarzi and Langerodi, 2013; Nguyen et al., 2015). Various scales and indexes to measure service quality such as SERVQUAL (Parasuraman et al., 1985, 1988), Technical and Functional Quality model (Gronroos, 1984), Synthesized model of service quality (Brogowicz et al., 1990), Antecedents and mediator model (Dabholkar et al., 2000; Mittal and Kamakura, 2001) have been developed and extensively used by academics and practitioners. SERVQUAL is often considered the most commonly applied in numerous empirical studies in many countries (Aphunu and Otoikhian, 2008; Ladhari, 2009; Cameran et al., 2010). SERVQUAL scale was originally developed by Parasuraman et al. in 1985 by comparing expectations with perceptions on 10 service quality aspects. By 1988, this scale was further identified with five service quality dimensions: Tangible, Reliability, Responsiveness, Assurance, and Empathy (Hamzah et al., 2015). In this study, the conceptual framework is developed following various empirical and theoretical studies such as Parasuraman et al. (1985), Anderson et al. (2008), and Nguyen et al. (2015). The linear structural model (SEM) is used to estimate the relationship between the factors reflecting the quality of extension services and the farmers' satisfaction. From previous studies, we selected five factors as mentioned above reflecting the quality of $\mathrm{AE}$ services (Figure 2).

Six variables measure the factor of tangible: Full teaching equipment (TG1); Modern teaching equipment (TG2); Convenient place to study (TG3); The venue for wellorganized classes (TG4); Good combination of AE organizing 


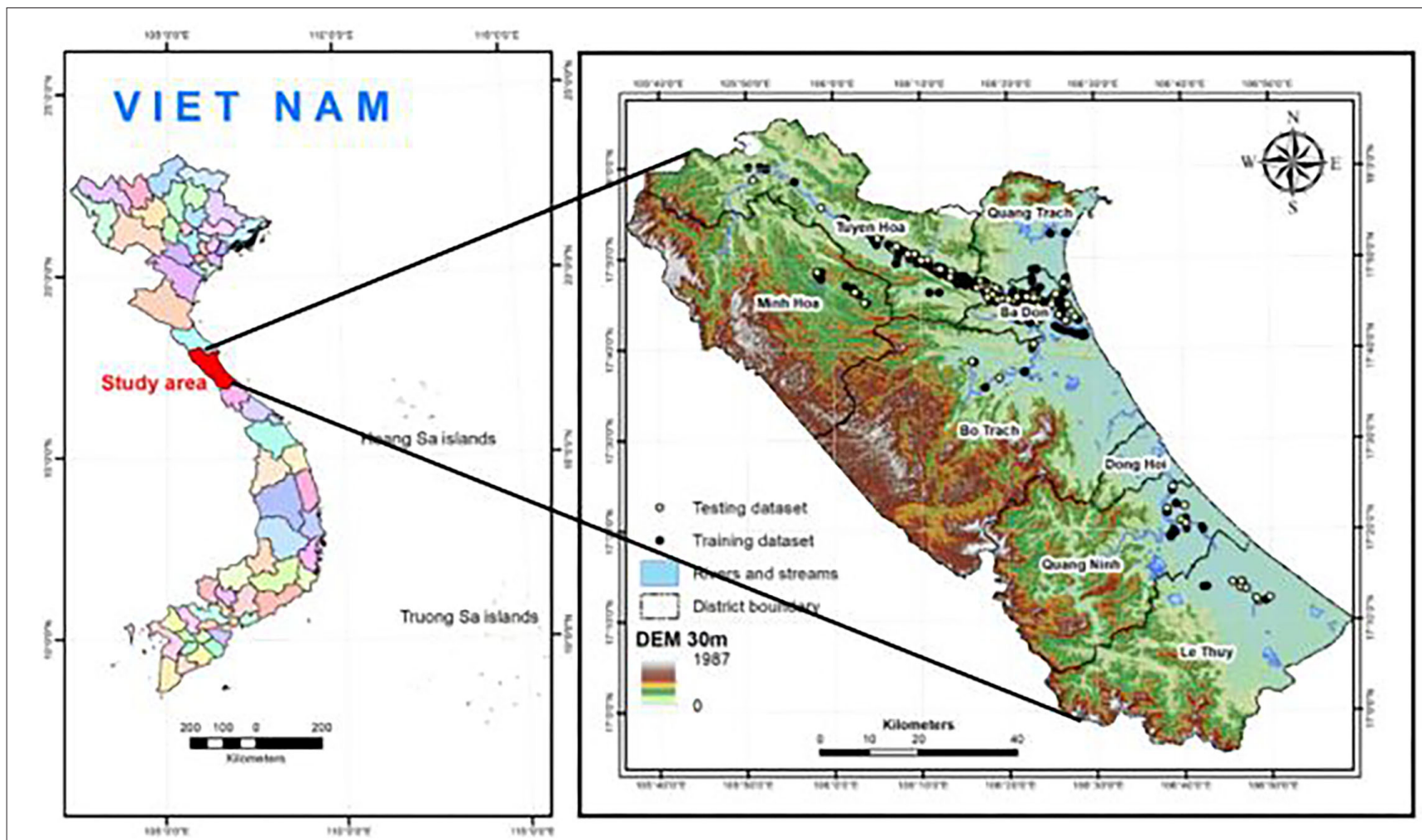

FIGURE 1 | Quang Binh province in Vietnam's map.

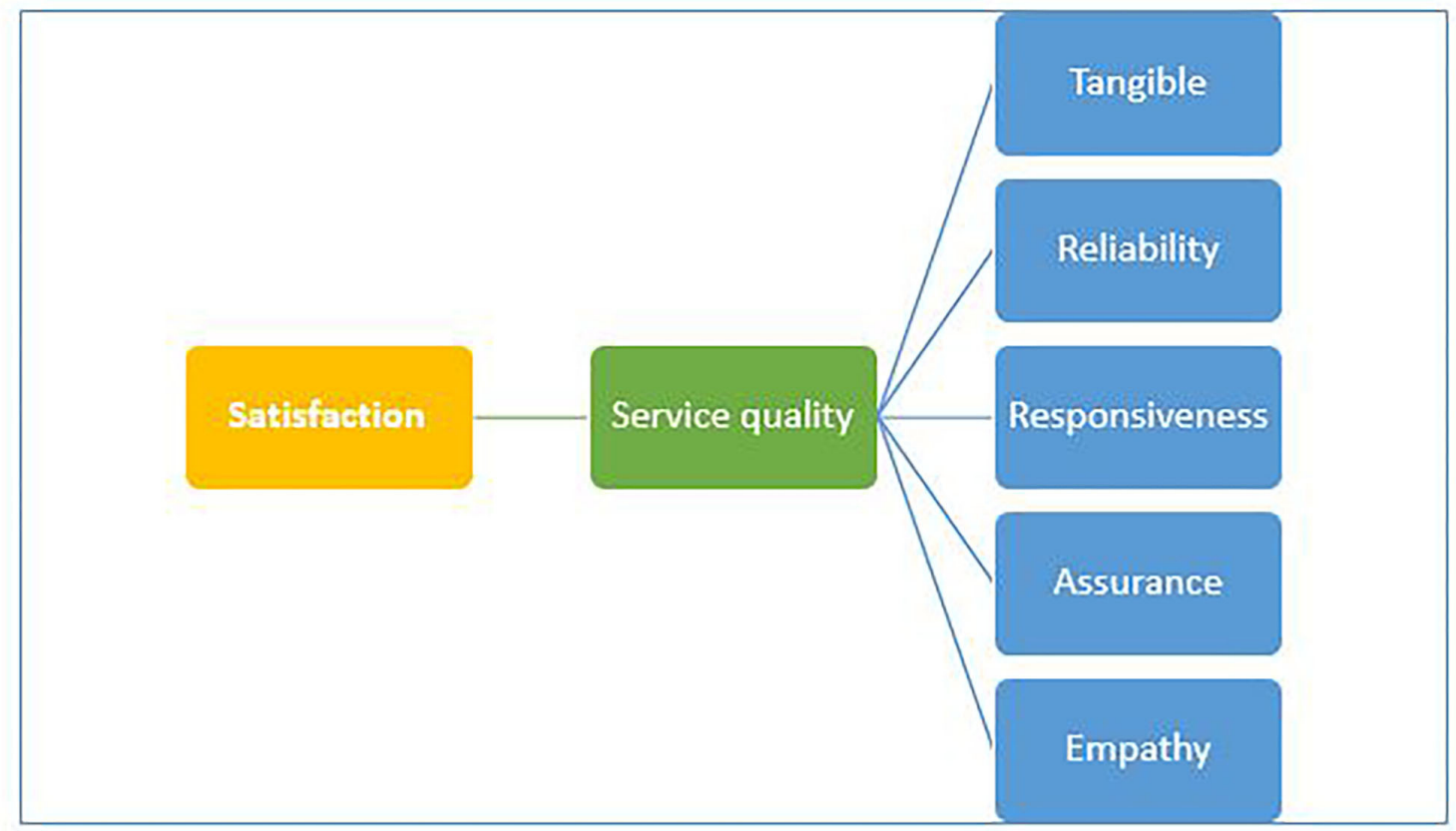

FIGURE 2 | Conceptual framework of the impact of service quality and farmer's satisfaction. 
committee (TG5); The center's support in the programs is appropriate (TG6).

Five variables measure the reliability factor: $\mathrm{AE}$ Center always fulfills its commitments (RLA1); The AE Center is always interested in farmers' problems (RLA2); The AE Center provides accurate information that farmers need (RLA3); AE Center provides information at the right time (RLA4); The AE Center always announces the program implementation time (RLA5).

Four variables measure responsiveness factor: AE staff with good professional knowledge (RSP1); AE officers always help farmers (RSP2); AE staff answer questions thoroughly (RSP3); AE staff enthusiastically guide farmers in practice (RSP4).

Five variables measure assurance factor: Farmers feel secure when applying advances in production (ASR1); Clear presentation and easy to understand instructions (ASR2); Lively, relaxed classroom communication (ASR3); Experienced AE Officer (ASR4); Matching field trips (ASR5).

Four variables measure empathy factor: AE program activities are suitable for farmers' needs (EPT1); AE staff sympathize with the difficulties of farmers (EPT2); AE activities with convenient working time (EPT3); Close and friendly extension staff (EPT4).

The Likert scale is used to assess the level of farmers' satisfaction: 1: Very dissatisfied; 2: Dissatisfied; 3: Normal; 4: Satisfied; 5: Very satisfied.

The estimation process consists of two stages: the first stage is to evaluate the validity of the measurement model, and the second stage is to test the structural model. Confirmatory factor analysis (CFA) was used in the first stage. Two necessary criteria for the measurement model to be valid are the acceptability of the model fit and the validity of the factors (Mittal and Kamakura, 2001; Hair et al., 2012). Regarding the fit of the model, there are many indicators classified. The rule of thumb is to use the Chisquare test and at least 1 criterion from each group (Hair et al., 2012). Other SEM studies often use the Chi-square test and one or more indicators from groups (Flynn et al., 1990; Lee et al., 2000; Van der Veen and Song, 2013).

The second stage is to run the SEM model and use the same evaluation criteria as the CFA. Then there are interpretations of the path coefficient, structural model fit $\left(\mathrm{R}^{2}\right)$, direct, indirect, and total effects.

\section{Data Collection}

Secondary data were collected from DARD, AEC of Quang Binh Province, and Districts' Agriculture Departments. Primary data was collected by stratified sampling method combined with randomization. In each district in the province, the study randomly selected two communes to investigate (total 12 communes for six districts). According to Moore's formula (Moore, 2003), the sample size was estimated based on the total number of households in each district, and the error allowed $5 \%$. The sample size was determined to be 455 households. Households are selected randomly from the list provided by the Commune People's Committee. They were interviewed using a prepared questionnaire. The content of the interviews included general information about farmers, agricultural production, participation, and satisfaction with different aspects of local AE services.

\section{RESEARCH RESULTS}

\section{Overview About AE System in Vietnam}

The Vietnamese Government's public extension system was established in 1993, and it is divided into five levels: Central (National), Provincial, District, Commune, and Village/Hamlet.

The Vietnam Extension System was formally created on March 2, 1993, under Government Decree 13/N-CP. According to this order, MARD was designated as the management's primary focal point. Based on these findings, the Government founded the National Agriculture Extension Center in 1998. The Center is responsible for the following tasks, according to current regulations: (i) Developing management policies and management mechanisms for $\mathrm{AE}$, forestry, fishery, and rural industry; (ii) developing economic-technical cost-norms for extension works; leading, organizing, and guiding the transfer of advanced techniques through demonstration models, information dissemination, training, and service provision. (iii) establishing economictechnical cost-norms for extension works; leading, organizing, and guiding the transmission of innovative methods through establishing demonstration models, information dissemination, training, service provision, and international collaboration in relevant sectors.

The total number of public extension workers in Vietnam (as of December 31,2018 ) is 34,747 , equating to one public extension worker for every 280 agricultural families. Each of the 63 provinces/cities has its own Extension Center, with an average of 30 people percenter. Only 585 of the total 648 districts have Extension Stations (90,3 percent) under the supervision of the provincial extension Centers (average six people per station) (Ministry of Agricultural Rural Development, 2019).

Current extension activities are centered on the following topics:

(i) Creating models that demonstrate sophisticated approaches for transmission to farmers. The models emphasize the introduction of new kinds, methods, and technologies. Parallel to this, extension personnel arranges field days to teach farmers and answer their concerns.

(ii) Planning farmer training. Because not all new techniques are shown in the fields, training swiftly transfers them to farmers. Furthermore, the extension system provides possibilities for farmers to use innovative technology from other countries.

(iii) Hosting science and technology forums and particular festivals and exhibitions, where farmers may interact directly with scientists, managers, and examples of successful cases of using new technology.

Aside from transferring technology and training, the extension system is also in charge of communicating new agricultural policies to farmers, rural regions, and markets. Meanwhile, extension workers gather input on shortcomings and restrictions from practices to propose new technologies or change rules (Nguyen and Nguyen, 2016).

Today, the following players participate in extension duties: (i) the government extension system (Extension centers); (ii) research institutions; (iii) universities; (iv) businesses; 
(v) non-governmental organizations (NGOs); (vi) volunteer extension organizations.

The future of extension in Vietnam is to foster "socialization of the extension program." The goal is to promote two-way information exchange and develop farmer-led and demanddriven extensions (Ministry of Agricultural Rural Development, 2019).

\section{Analysis of Factors Affecting the Quality of AE Programs in Quang Binh}

The main objective of the AE policy is to impart knowledge to farmers in the locality, helping them make the right decisions in the face of situations arising in the production process. Local AE forms in Quang Binh are quite diverse (Table 1).

The results show that the most common form of $\mathrm{AE}$ is training directly guided by extension center staff (41.5\%). In addition, farmers have access to technical advances through information and communication channels, demonstration models, and consulting services for extension services (32.9\%). Regarding the level of participation of farmers in the AE program, each household participates on average twice a year (58.2\%) and three times $(26.1 \%)$.

\section{Evaluation of the Reliability of the Scale With Cronbach's Alpha Coefficient}

The quality of the AE program is measured by five factors: Tangible, Reliability, Responsiveness, Assurance, and Empathy. The results of testing the reliability of the scale with Cronbach's Alpha coefficient (Table 2) show that all service quality factors have the accepted Cronbach's Alpha coefficient of $>0.6$ (Peterson, 1994). The total correlation coefficient of the variables in the scale is $>0.3$, and it is satisfactory (Hair et al., 2010), so the measurement variables of these factors are used for EFA analysis.

TABLE 1 | Local AE forms in Quang Binh.

\begin{tabular}{lcc}
\hline Forms of AE & Number of households & Percentage \\
\hline Training & 189 & 41.5 \\
Information and communication & 135 & 29.7 \\
Demonstration model of AE & 38 & 8.3 \\
Consulting AE services & 150 & 32.9 \\
\hline
\end{tabular}

TABLE 2 | Cronbach's Alpha factors of service quality scale AE.

\begin{tabular}{llc}
\hline Factors & & Cronbach's alpha \\
\hline Tangible Media & TG1, TG2, TG3, TG4, TG5, TG6 & 0.760 \\
Reliability & RLA1, RLA2, RLA3, RLA4, RLA5 & 0.869 \\
Responsiveness & RPS1, RPS2, RPS3, RPS4 & 0.728 \\
Assurance & ASR1, ASR2, ASR3, ASR4, AR5 & 0.832 \\
Empathy & EPT1, EPT2, EPT3, EPT4 & 0.851 \\
Service quality & SQ1, SQ2, SQ3 & 0.759 \\
Satisfaction & STF1, STF2, STF3 & 0.839
\end{tabular}

\section{Exploratory Factor Analysis (EFA)}

EFA results with factor extraction using Principal Axis Factoring, and Promax non-perpendicular rotation showed five factors extracted with the extracted variance of $68.52 \%$ (>50\%) meeting the requirements. However, in 24 observed variables, seven observed variables (TG5, TG6, RLA4, RLA5, RSP3, RSP4, ASR5) have factor loading $<0.5$, so they are excluded from the model (Fornell, 1992; Fornell et al., 1996; Allen and Rao, 2000; Amin and Isa, 2008). After eliminating seven unsatisfactory variables, the final EFA results are presented in Table 3. KMO and Ballett's test in EFA factor analysis shows that $\mathrm{KMO}=0.668$ is satisfactory due to $>0.5$ and Sig. $=0.000$. The TLI $=0.872$, CFI $=0.912 \geq 0.9$, RMSEA $=0.055 \leq 0.08$, then the model fits the research data. The model's fit with the research data shows that the necessary and sufficient conditions for the observed variables are unidirectional (Saravanan and Rao, 2007). The factors Assurance, Empathy, Reliability, and Responsiveness achieve unidirectionality.

\section{Farmers' Satisfaction With the Quality of the AE Program}

Research results (Table 4) show that the quality of the extension program has a positive influence and strongly correlates with the satisfaction of farmers, as shown by the coefficient $\beta=$ 0.715 . This estimate reaches statistical significance at $p=0.000$. This means that farmer satisfaction increases as the quality of local extension programs is improved. Extension program quality includes factors such as assurance, empathy, credibility, tangibles, and responsiveness. In which the Assurance has the greatest influence on the quality of the $\mathrm{AE}$ program, the estimation results of the SEM show that the assurance factor has the

TABLE 3 | EFA results of service quality scale.

\begin{tabular}{|c|c|c|c|c|c|}
\hline \multirow[t]{2}{*}{ Variables } & \multicolumn{5}{|c|}{ Factors } \\
\hline & 1 & 2 & 3 & 4 & 5 \\
\hline ASR4 & 0.815 & & & & \\
\hline ASR3 & 0.779 & & & & \\
\hline ASR2 & 0.771 & & & & \\
\hline ASR1 & 0.692 & & & & \\
\hline ASR5 & 0.630 & & & & \\
\hline TG3 & & 0.908 & & & \\
\hline TG4 & & 0.898 & & & \\
\hline TG1 & & 0.865 & & & \\
\hline TG2 & & 0.792 & & & \\
\hline EPT1 & & & 0.831 & & \\
\hline EPT3 & & & 0.811 & & \\
\hline EPT2 & & & 0.771 & & \\
\hline EPT4 & & & 0.768 & & \\
\hline RLA2 & & & & 0.801 & \\
\hline RLA1 & & & & 0.796 & \\
\hline RLA3 & & & & 0.742 & \\
\hline RSP2 & & & & & 0.859 \\
\hline RSP1 & & & & & 0.833 \\
\hline
\end{tabular}


TABLE 4 | Relationship between AE service quality factors and satisfaction.

\begin{tabular}{lccc}
\hline & B Coefficient & SE & $\boldsymbol{p}$-value \\
\hline Tangible & -0.773 & 0.075 & 0.328 \\
Assurance & 0.666 & 0.052 & $0.000^{\star \star \star}$ \\
Empathy & 0.079 & 0.031 & $0.003^{\star \star \star}$ \\
Reliability & 0.121 & 0.048 & $0.018^{\star \star}$ \\
Responsiveness & -0.012 & 0.062 & 0.686 \\
Service quality & 0.715 & 0.076 & $0.000^{\star \star \star}$ \\
\hline
\end{tabular}

*** Statistically significant at the $1 \%$ level.

${ }^{* *}$ Statistical significance at $5 \%$ level.

coefficient $\beta=0.666$ and the reliability level of $99 \%$. Thus, the quality of the AE program will be improved when factors such as the experience of the extension staff, presentation methods, classroom discussions, application of advances in production, and field trips are more improved. Moreover, the SEM model also shows that the Reliability and Empathy factors significantly influence the quality of the local AE program.

However, the model shows that tangible and responsiveness factors are negatively related and not statistically significant to the quality of the extension program. This may be because the facilities and learning conditions in AE activities have not met the expectations of participating farmers and the professional quality of local extension workers.

\section{DISCUSSIONS}

The results of the analysis of the linear structural model (SEM) show the suitability of the theoretical model with the quality of the extension program and the satisfaction of farmers with local AE services in Quang Binh province, Vietnam. Research has shown that, as the quality of the extension program increases, the satisfaction level of farmers will also increase. On the other hand, the service quality of the AE program depends greatly on the assurance factor, the reliability factor, and the empathy factor. On the contrary, it does not depend on tangible factors and responsive factors.

These findings are consistent with the results of Gwala et al. (2016), Baiyegunhi and Majokweni (2019) and Awatade et al. (2019), who associated assurance factor with farming households' satisfaction with $\mathrm{AE}$ services. In spite of the importance of diversify farming activities for using resources efficiently, reducing economic risks for farmer and setting stabler ecosystem for farming effect positively on farmer satisfaction. This result is consistent with results by Buadi et al. (2013). Moreover, reliability factor and farmers' participation in $\mathrm{AE}$ services influenced significantly farmer satisfaction (Damisa et al., 2008; Suvedi et al., 2017). As AE the main source of farming households' information on innovations, their participation increased in frequency. AE services in Vietnam mainly arrange group methods such as meetings to transfer extension information. Farmers can attend these meetings because of the active role of local authorities. This result is consistent with those of previous papers (Kassem, 2015; Lalhmachhuana and Devarani,
2016; Nahayo et al., 2017) which showed the significant roles of participating in AE in improving farmer satisfaction.

The results also indicate that empathy factors are significant positively correlated with satisfaction. The fact that AE program activities are suitable with farmers' needs, AE staff sympathize with the difficulties of farmers and AE activities are convenient working time increase famers' satisfaction have been confirmed in some related studies as one of the main factors influencing satisfaction (Yazdanpanah et al., 2013; Gwala et al., 2016). In Vietnam, local agricultural extension organizations often have very close relationships with farmers. Through regular interaction with local organizations such as women's unions, veterans' unions, farmers' unions, and youth unions, these extension organizations are able to grasp the difficulties in the production process. local agriculture, needs and information to be shared with farmers. This makes it possible for extension organizations to design shares, suggestions and messages to suit farmers' needs, in the way they expect.

Results showed that tangible factor is not significant determinant for satisfaction. This is may be attributed to the fact that the several farming households in Quang Binh province do not want to rely too much on modern farming equipments. They also don't need formal classes or tangible support such as lectures, handouts or demonstration clips. What they want are messages that are short, clear, and make their farming operations productive. This is consistent with the study by Yazdanpanah (2016) that when the education level of farmers is not high, the tangible factors in $\mathrm{AE}$ do not have too much influence on their satisfaction with extension services. However, other studies (e.g., Gwala et al., 2016; Morris et al., 2017; Bruce and Costa, 2019) reported the significant effect of education on increasing farmer satisfaction.

\section{CONCLUSIONS AND RECOMMENDATIONS}

The mission of AE is to bridge farmers with science, production techniques, optimal farming, opening new opportunities, and creating sustainable values. In Vietnam, when the agricultural sector is facing a change in growth pattern in the context of globalization and climate change, AE work needs to revolve around farmers, understanding the problems they are facing, providing suitable advices and supports to help farmers cultivate more efficiently. Good knowledge may help to increase the productivity of crops and livestock, to get the more output and profit. However, knowledge and skills alone are not enough, it is the attitude in work that is decisive. When farmers are optimistic and firmly believe that they can do it, they can definitely do it, agricultural extension work will have many advantages. When farmers are pessimistic, lack confidence in themselves, and trust in the community, it is difficult for agricultural extension work to be widely deployed. AE, besides providing technology, must also instill confidence in farmers through factors such as reliability and empathy.

This study assesses the satisfaction of farmers with AE services in Quang Binh province, Vietnam. The results of a survey 
with farmers show a positive relationship between quality and satisfaction. Factors such as assurance, reliability, and sympathy are important factors in AE service quality.

These are the bases for building an effective solution in training farmers to achieve the requirements of transferring scientific and technical progress and satisfying the needs of farmers participating in the program. In this analysis, for farmers to confidently apply scientific advances to agricultural production, AE activities need to add other support policies such as product consumption, lending policies, agricultural insurance. In addition, the model of socialization of $\mathrm{AE}$ should also be replicated to mobilize capital from the people and businesses trading in agricultural materials to reduce the budget burden and take advantage of the resources of the private sector. AE activities are often related to application and technology transfer, requiring investment in facilities and funding to maintain and replicate the model. Therefore, AE agencies should actively cooperate with

\section{REFERENCES}

Allen, D. R., and Rao, T. R. (2000). Analysis of Customer Satisfaction Data: A Comprehensive Guide to Multivariate Statistical, Loyalty and Service Quality Research. Milwauke:ASQ Quality Press.

Amin, M., and Isa, Z. (2008). An examination of the relationship between service quality perception and customer satisfaction: a SEM approach towards Malaysian Islamic banking. Int. J. Islamic Middle East. Finance Manag. 1, 191-209. doi: 10.1108/17538390810901131

Anderson, S., Pearo, L. K., and Wildener, S. K. (2008). Drivers of services satisfaction: linking customer satisfaction to the service concept and customer characteristics. J. Serv. Res. 10, 350-370. doi: 10.1177/1094670508314575

Aphunu, A., and Otoikhian, C. S. O. (2008). Farmers' perception of the effectiveness of extension agents of Delta State Agricultural Development Programme (DADP). Afr. J. General Agric. 4, 165-169.

Awatade, S. C., Ghosh, R. B., and Singandhupe, M. (2019). Extent of farmers' satisfaction from agricultural extension services in Maharashtra. Indian J. Extension Educ. 55, 1-7. doi: 10.20546/ijcmas.2018.703.001

Baiyegunhi, L. J. S., and Majokweni, S. R. D. (2019). Impact of outsourced agricultural extension program on smallholder farmers' net farm income in Msinga, KwaZulu-Natal, South Africa. Technol. Soc. 57, 21-33. doi: 10.1016/j.techsoc.2018.11.003

Brogowicz, A. A., Delene, L. M., and Lyth, D. M. (1990). A synthesised service quality model with managerial implications. Int. J. Serv. Ind. Manag. 1, 27-44. doi: 10.1108/09564239010001640

Bruce, K., and Costa, H. (2019). Enabling environment for PPPs in agricultural extension projects: policy imperatives for impact. J. Rural Studi. 70, 87-95. doi: 10.1016/j.jrurstud.2019.07.005

Buadi, K. A., Anaman, J. A., and Kwarteng, A. (2013). Farmers' perceptions of the quality of extension services provided by non-governmental organisations in two municipalities in the Central Region of Ghana. Agric. Syst. 120, 20-26. doi: 10.1016/j.agsy.2013.05.002

Cameran, M., Moizer, P., and Pettinicchio, A. (2010). Customer satisfaction, corporate image, and service quality in professional services. Serv. Ind. J. 30, 421-435. doi: 10.1080/026420608022 36111

Chavan, J., and Ahmad, F. (2013). Factors affecting on customer satisfaction in retail banking: an empirical study. Int. J. Bus. Manag. Invent. 2, 55-62.

Dabholkar, P. A., Shepherd, C. D., and Thorpe, D. I. (2000). A comprehensive framework for service quality: an investigation of critical conceptual and measurement issues through a longitudinal study. J. Retail. 76, 131-139. doi: 10.1016/S0022-4359(00)00029-4 research organizations and enterprises to test and demonstrate local models.

\section{DATA AVAILABILITY STATEMENT}

The original contributions presented in the study are included in the article/supplementary material, further inquiries can be directed to the corresponding author/s.

\section{AUTHOR CONTRIBUTIONS}

The author confirms being the sole contributor of this work and has approved it for publication.

\section{FUNDING}

This work was supported by the National Economics University, Vietnam.
Damisa, M. A., Abdulsalam, Z., and Kehinde, A. (2008). Determinants of farmers' satisfaction with their irrigation system in Nigeria. Trend. Agric. Econ. 1, 8-13. doi: $10.3923 /$ tae.2008.8.13

Dang, L. H., Li, E., and Bruwer, J. (2012). Understanding climate change adaptive behaviour of farmers: an integrated conceptual framework. Int. J. Clim. Change 3, 255-272. doi: 10.18848/1835-7156/CGP/v03i02/37106

FAO (2020). The State of Food Security and Nutrition in the World (SOFI): Transforming Food Systems for Affordable Healthy Diets. FAO, Rome. Available online at: https://www.fao.org/3/ca9692en/ca9692en.pdf

Faramarzi, N., and Langerodi, M. C. (2013). Investigating farmers' attitude regarding advisory services of agricultural technical and engineering in Sari Township. Int. J. Agric. Crop Sci. 5, 2878-2884.

Faure, Y., Desjeux, P., and Gasselin, S. (2012). New challenges in agricultural advisory services from a research perspective: a literature review, synthesis and research agenda. J. Agric. Educ. Extension 18, 461-492. doi: 10.1080/1389224X.2012.707063

Flynn, B., Sakakibara, S., Schroeder, R., Bates, K., and Flynn, E. (1990). Empirical research methods in operations management. J. Oper. Manag. 9, 250-284. doi: 10.1016/0272-6963(90)90098-X

Fornell, C. (1992). A national customer satisfaction barometer: the Swedish experience. J. Market. 56, 6-21. doi: 10.2307/1252129

Fornell, C., Johnson, M., Anderson, E., Cha, J., and Bryant, B. (1996). The American customer satisfaction index: nature, purpose, and findings. J. Market. 60, 7-18. doi: 10.2307/1251898

Getty, M. J., and Getty, L. R. (2003). Lodging quality index (LQI): Assessing customers' perceptions of quality delivery. Int. J. Contemp. Hosp. 15, 94-104. doi: 10.1108/09596110310462940

Gronroos, C. (1984). A service quality model and its marketing implications. European J. Market. 18, 36-44. doi: 10.1108/EUM0000000004784

Gwala, N., Monde, V., and Muchenje, J. (2016). Effect of agricultural extension services on beneficiaries of the Nguni cattle project in the Eastern Cape Province, South Africa: a case study of two villages. Appl. Anim. Husbandry Rural Dev. 9, 31-40.

Hair, J. F., Black, W. C., Babin, B. J., and Anderson, R. E. (2010). Multivariate Analysis, 7th Edn. New York, NY: Pearson

Hair, J. F., Sarstedt, M., Pieper, T., and Ringle, C. M. (2012). The use of partial least squares structural equation modeling in strategic management research: a review of past practices and recommendations for future applications. Long Range Plann 45, 320-340. doi: 10.1016/j.lrp.2012.09.008

Hamzah, Z., Lee, S., and Moghavvemi, S. (2015). Elucidating perceived overall service quality in retail banking. Int. J. Bank Market. 35, 781-804. doi: 10.1108/IJBM-12-2015-0204 
Hossain, M. J. (2012). Impact of service quality on customer satisfaction: a case of tourism industry in Bangladesh. Int. J. Res. Finance Market. 2, 1-25. doi: 10.1504/IJLTM.2011.038885

Kassem, H. S. (2015). Administrative reform and organizational change at agricultural extension organizations: a longitudinal study of central administration of agricultural extension. J. Agric. Econ. Soc. Sci. 6, 755-769. doi: 10.21608 /jaess.2015.38951

Ladhari, R. (2009). A review of twenty years of SERVQUAL research. Int. J. Qual. Serv. Sci. 1, 172-198. doi: 10.1108/17566690910971445

Lalhmachhuana, L., and Devarani, N. (2016). Assessment of clientele satisfaction of selected KVKs in Mizoram. Indian J. Hill Farm. 29, 162-168.

Lee, H., Lee, Y., and Yoo., D. (2000). The determinants of perceived service quality and its relationship with satisfaction. J. Serv. Market. 14, 212-225. doi: 10.1108/08876040010327220

Ministry of Agricultural and Rural Development (2019). 20 Years of Vietnam's Agricultural Extension Sector. Hanoi: National Political Publishing House (in Vietnamese).

Mittal, V., and Kamakura, W. A. (2001). Satisfaction, repurchase intent and repurchase behaviour: investigating the moderating effect of customer characteristics. J. Market. Res. 38, 122-135. doi: 10.1509/jmkr.38.1.131. 18832

Moore, S. D. (2003). Practice of Statistics. New York, NY: W. H. Freeman and Company.

Morris, A., Henley, D., and Dowell, L. (2017). Farm diversification, entrepreneurship and technology adoption: analysis of upland farmers in Wales. J. Rural Stud. 53, 132-143. doi: 10.1016/j.jrurstud.2017.05.014

Nahayo, M. O., Omondi, X. H., Zhang, L. Q., Li, G. X., and Pan, S. (2017). Factors influencing farmers' participation in crop intensification program in Rwanda. J. Integr. Agric. 16, 1406-1416. doi: 10.1016/S2095-3119(16) 61555-1

Nguyen, D., Rieu, I., Mariani, C., and Dam, N. M. (2016). How plants handle multiple stresses: hormonal interactions underlying responses to abiotic stress and insect herbivory. Plant Mol. Biol. 91, 727-740. doi: 10.1007/s11103-016-0481-8

Nguyen, H., M., Nguyen, T, H., Phan, C., A., and Yoshiki, M. (2015). Service quality and customer satisfaction: a case study of hotel industry in Vietnam. Asian Soc. Sci. 11, 73-85. doi: 10.5539/ass.v11n10p73

Nguyen, H., T., and Nguyen, N, C. (2016). Policy on agricultural and fishery extension in the world gender and suggestions for improvement of promotion policies fish for aquaculture in coastal areas Northern Vietnam. Vietnam Agric. Sci. J. 2, 202-210.

Parasuraman, A., Zeithaml, V. A., and Berry, L. L. (1985). A conceptual model of Service quality and its implications for future research. J. Market. 49, 43-49. doi: $10.2307 / 1251430$
Parasuraman, A., Zeithaml, V. A., and Berry, L. L. (1988). SERVQUAL: a multipleitem scale for measuring consumer perceptions of service quality. J Retail. 64, 12-37.

Peterson (1994). A meta-analysis of cronbach's coefficient alpha. J. Consum. Res. 21, 38-91. doi: 10.1086/209405

Quang Binh People Committee (2020). Socio- Economic Development Report. Quang Binh Province (in Vietnamese).

Saravanan, R., and Rao, K. S. P. (2007). Measurement of service quality from the customer's perspective-an empirical study. Total Qual. Manag. 18, 435-449. doi: 10.1080/14783360701231872

Suvedi, R., Ghimire, M., and Kaplowitz, T. (2017). Farmers' participation in extension programs and technology adoption in rural Nepal: a logistic regression analysis. J. Agric. Educ. Extension 23, 351-371. doi: 10.1080/1389224X.2017.1323653

Van der Veen, R., and Song, H. (2013). Impact of the perceived image of celebrity endorsers on tourists' intentions to visit. J. Travel Res. 53, 211-224. doi: $10.1177 / 0047287513496473$

World Bank. (2020). Vietnam Overview: Development News, Research and Data. Hanoi: World Bank.

Yazdanpanah, G. H., Zamani, S., Hochrainer-Stigler, N., and Monfared, J. (2013). Measuring satisfaction of crop insurance a modified American customer satisfaction model approach applied to Iranian Farmers. Int. J. Disaster Risk Reduct. 5, 9-27. doi: 10.1016/j.ijdrr.2013.04.003

Yazdanpanah, N. (2016). Spatiotemporal mapping of groundwater quality for irrigation using geostatistical analysis combined with a linear regression method. Model. Earth Syst. Environ. 2, 1-13. doi: 10.1007/s40808-015-0071-9

Conflict of Interest: The author declares that the research was conducted in the absence of any commercial or financial relationships that could be construed as a potential conflict of interest.

Publisher's Note: All claims expressed in this article are solely those of the authors and do not necessarily represent those of their affiliated organizations, or those of the publisher, the editors and the reviewers. Any product that may be evaluated in this article, or claim that may be made by its manufacturer, is not guaranteed or endorsed by the publisher.

Copyright (C) 2022 Truong. This is an open-access article distributed under the terms of the Creative Commons Attribution License (CC BY). The use, distribution or reproduction in other forums is permitted, provided the original author $(s)$ and the copyright owner(s) are credited and that the original publication in this journal is cited, in accordance with accepted academic practice. No use, distribution or reproduction is permitted which does not comply with these terms. 